\title{
FAKTOR-FAKTOR DOMINAN YANG MEMPENGARUHI PRODUKTIVITAS TAMBAK DI KABUPATEN PINRANG, SULAWESI SELATAN
}

\author{
Akhmad Mustafa*) dan Erna Ratnawati*)
}

\begin{abstract}
ABSTRAK
Kabupaten Pinrang memiliki tambak terluas di Provinsi Sulawesi Selatan dan ditetapkan sebagai pusat pengembangan produksi udang windu, namun produktivitas tambaknya masih relatif rendah. Oleh karena itu, dilakukan penelitian yang bertujuan untuk mengetahui faktor-faktor dominan yang berpengaruh terhadap produktivitas tambak di Kabupaten Pinrang. Sebagai peubah tergantung adalah produktivitas tambak, sedangkan sebagai peubah bebas adalah faktor-faktor status pembudi daya tambak, kondisi tambak, pengelolaan tambak, kualitas air tambak, dan kualitas tanah tambak yang masing-masing terdiri atas $9,11,31,11$, dan 17 peubah. Regresi berganda dengan peubah boneka digunakan untuk menganalisis data untuk memprediksi peubah tergantung. Hasil penelitian menunjukkan bahwa produktivitas tambak di Kabupaten Pinrang rata-rata $499 \mathrm{~kg} / \mathrm{ha} /$ musim. Produktivitas tambak di Kabupaten Pinrang masih dapat ditingkatkan melalui penambahan tenaga kerja dan pemisahan saluran pemasukan dan pengeluaran air serta penambahan tinggi pematang agar tinggi air juga dapat ditingkatkan. Aplikasi pupuk urea pada saat persiapan tambak dan aplikasi urea dan SP-36 sebagai pupuk susulan dapat meningkatkan produktivitas tambak, sebaliknya aplikasi $\mathrm{KCl}$ pada saat persiapan tambak dapat menurunkan produktivitas tambak. Pengurangan kapur susulan dan peningkatan pupuk yang mengandung fosfat dapat meningkatkan produktivitas tambak.
\end{abstract}

ABSTRACT: Dominant factors that effect on the productivity of brackishwater ponds in Pinrang Regency, South Sulawesi. By: Akhmad Mustafa and Erna Ratnawati

Pinrang Regency has largest brackishwater ponds in South Sulawesi Province and determined as a centre for developing of shrimp production. However, their brackishwater ponds productivity is still low. Because of that, it was conducted research with aims to know the dominant factors that effect on the productivity of brackishwater pond in Pinrang Regency. As a dependent variable in this research was productivity of brackishwater ponds. Independent variables were grouped into: (a) farmer status factor, consist of 9 variables; (b) pond condition factor, consist of 11 variables; (c) pond management factor, consist of 31 variables; (d) water quality factor, consist of 11 variables and (e) soil quality factor, consist of 17 variables. Multiple regressions with dummy variable were used to analyze the data in predicting dependent variable. The results showed that the productivity of brackishwater pond in Pinrang Regency was $499 \mathrm{~kg} / \mathrm{ha} / \mathrm{cycle}$ in average. The productivity of brackishwater pond could be increased through addition of labor and separating of outlet and inlet canals and making higher the pond dyke for increasing the water depth. Application of urea fertilizer as an initial fertilizing and application urea and SP-36 as a continuing fertilizing could be increased the brackishwater pond productivity. In contrary, application of $\mathrm{KCl}$ fertilizer as an initial fertilizing would be decreased the brackishwater ponds productivity. Decreasing of continuing liming and increasing the fertilizer containing phosphate would be increased the brackishwater ponds productivity in Pinrang Regency.

KEYWORDS: dominant factors, productivity, brackishwater pond, South Sulawesi

Peneliti pada Balai Riset Perikanan Budidaya Air Payau, Maros 


\section{PENDAHULUAN}

Jenis perikanan budi daya yang dilakukan di Indonesia meliputi budi daya laut, budi daya tambak, budi daya kolam, dan budi daya sawah. Di antara berbagai jenis perikanan budi daya tersebut, produksi tertinggi yaitu 559.612 ton $(38,10 \%$ dari total produksi perikanan budi daya) berasal dari budi daya tambak dengan luas mencapai 489.811 ha (luas kotor) pada tahun 2004 (Anonim, 2006). Usaha perikanan budi daya tambak merupakan kegiatan yang memanfaatkan kawasan pesisir yang mampu memberikan kontribusi cukup besar terhadap pendapatan masyarakat pesisir, penyedia lapangan kerja, dan perolehan devisa negara yang potensial. Sulawesi Selatan merupakan salah satu sentra produksi budi daya tambak dan memiliki tambak terluas yaitu 104.240 ha atau sekitar 21,28\% dari total luas tambak di Indonesia pada tahun 2004.

Tambak terluas di Sulawesi Selatan dijumpai di Kabupaten Pinrang yaitu seluas 15.853 ha ( $16,51 \%$ dari total tambak di Sulawesi Selatan) pada tahun 2005 (Anonim, 2005) dan ditunjuk sebagai pusat pengembangan produksi udang windu di Sulawesi Selatan. Komoditas selain udang windu (Penaeus monodon) yang dibudidayakan di tambak Kabupaten Pinrang adalah ikan bandeng (Chanos chanos), baik secara monokultur maupun polikultur dengan produksi 2.237 ton udang windu dan 9.420 ton ikan bandeng pada tahun 2005 (Anonim, 2005). Produktivitas tambak di Kabupaten Pinrang baru mencapai $141 \mathrm{~kg} / \mathrm{ha} /$ tahun untuk udang windu dan 594 $\mathrm{kg} / \mathrm{ha} /$ tahun untuk ikan bandeng. Produktivitas tambak ini masih dapat ditingkatkan melalui pengelolaan tambak yang tepat dan penerapan teknologi yang sesuai dengan kesesuaian lahan tambak.

Pengelolaan tambak yang dilakukan oleh pembudi daya tambak sangat bervariasi, termasuk pembudi daya tambak di Kabupaten Pinrang, sebagai contoh kapur yang diaplikasikan berkisar antara 150 sampai 2.500 $\mathrm{kg} / \mathrm{ha}$ dan padat penebaran benur windu antara 10.000 sampai 30.000 ekor/ha dan nener bandeng antara 500-2.500 ekor/ha pada polikultur udang windu dan ikan bandeng (Ratnawati et al., 2002). Pemupukan dan pengapuran serta ketersediaan air dan adanya saluran memberikan pengaruh yang nyata terhadap produktivitas tambak di Kabupaten Maros, Takalar, dan Bulukumba - Sulawesi Selatan (Hanafi, 1990). Di tambak tanah sulfat masam yang berlokasi di Kecamatan Walenrang, Kabupaten Luwu, Sulawesi Selatan produksi rumput laut sangat ditentukan oleh dosis pupuk urea, luas tambak, pengalaman petambak, dosis pupuk $\mathrm{KCl}$, umur tambak, padat penebaran nener bandeng, dan dosis kapur yang diaplikasikan (Mustafa \& Ratnawati, 2005). Oleh karena itu, perlu upaya untuk mengetahui faktor pengelolaan yang berpengaruh terhadap produktivitas tambak yang diharapkan dapat menjadi bahan pertimbangan dalam upaya peningkatan produktivitas tambak. Selain itu, faktor lingkungan tambak juga perlu diketahui yang sekaligus merupakan upaya untuk melakukan modifikasi kriteria dalam penentuan kelayakan tambak. Pengelolaan tambak merupakan faktor penting setelah penentuan kelayakan Iahan budi daya tambak dalam rangka pengembangan ilmu pengetahuan dan budi daya tambak berkelanjutan (Karthik et al., 2005). Oleh karena itu, dilakukan penelitian yang bertujuan untuk mengetahui faktor-faktor dominan yang berpengaruh terhadap produktivitas tambak di Kabupaten Pinrang, Sulawesi Selatan.

\section{BAHAN DAN METODE}

Penelitian dilaksanakan di kawasan pertambakan yang ada di Kabupaten Pinrang, Provinsi Sulawesi Selatan. Untuk mendapatkan informasi awal mengenai kegiatan budi daya tambak di Kabupaten Pinrang, maka dilakukan pertemuan dengan staf Dinas Perikanan dan Kelautan Kabupaten Pinrang di Pinrang. Penelitian diawali dengan melihat secara keseluruhan tambak yang ada di Kabupaten Pinrang. Titik-titik pengamatan atau tambak terpilih ditentukan secara acak dari Peta Mapping Unit (Satuan Pemetaan) yaitu gabungan Peta Landscape (Bentuk Lahan) dan Land Use (Penggunaan Lahan). Pembudi daya tambak dari tambak terpilih menjadi responden dalam penelitian ini.

Metode penelitian yang diaplikasikan adalah metode survai, termasuk untuk mendapatkan data primer dari produksi, status pembudi daya dan pengelolaan tambak yang dilakukan melalui pengajuan kuisioner kepada responden secara terstruktur (Wirartha, 2006). Kondisi tambak diketahui melalui pengamatan dan pengukuran langsung di lapangan. Kualitas air yang diukur secara in situ meliputi: $\mathrm{pH}$ dengan $\mathrm{pH}$-meter, suhu dengan termometer, salinitas dengan refraktometer, dan oksigen terlarut dengan 
DO-meter. Peubah kualitas air lainnya diketahui dengan pengambilan contoh air pada setiap petak tambak dan selanjutnya dipreservasi mengikuti petunjuk APHA (1998). Pengukuran dan pengambilan contoh air dilakukan dua kali yaitu pada saat musim kemarau dan musim hujan. Kualitas air yang dianalisis di Laboratorium Air Balai Riset Perikanan Budidaya Air Payau (BRPBAP) di Maros meliputi: $\mathrm{NH}_{3}$ dengan metode fenat, $\mathrm{NO}_{2}$ dengan metode kolorimetrik (APHA, 1998), $\mathrm{NO}_{3}$ dengan metode reduksi kadmium, $\mathrm{PO}_{4}$ dengan metode asam askorbik (APHA, 1998), $\mathrm{SO}_{4}$ dengan metode turbidimetrik, $\mathrm{Fe}$ dengan metode fenantrolin (APHA, 1998), dan padatan tersuspensi total dengan metode gravimetrik (APHA, 1998).

Untuk mengetahui kualitas tanah tambak maka dilakukan pengambilan contoh tanah pada kedalaman 0--0,20 m dasar tambak pada tiga tempat di setiap petak tambak yang selanjutnya dikomposit. Kualitas tanah yang diukur secara in situ adalah $\mathrm{pH}_{\mathrm{F}}(\mathrm{pH}$ tanah yang diukur langsung di lapangan) dengan $\mathrm{pH}$-meter (Ahern \& Rayment, 1998), $\mathrm{pH}_{\mathrm{Fox}}$ (pH tanah yang diukur di lapangan setelah dioksidasi dengan hidrogen peroksida 30\%) dengan $\mathrm{pH}$-meter (Ahern \& Rayment, 1998), redoks potensial dengan redox-meter dan tekstur dengan metode rasa (Menon, 1973). Untuk analisis peubah kualitas tanah lainnya, maka contoh tanah dimasukkan dalam cold box yang selanjutnya diberi es. Contoh tanah diovenkan pada suhu $80^{\circ} \mathrm{C}-85^{\circ} \mathrm{C}$ selama 48 jam untuk tanah sulfat masam (Ahern \& Blunden, 1998) dan dikeringanginkan untuk non-tanah sulfat masam dan selanjutnya dianalisis di Laboratorium Tanah BRPBAP di Maros. Kualitas tanah yang dianalisis di laboratorium meliputi $\mathrm{pH}_{\mathrm{KCl}}(\mathrm{pH}$ dari ekstrak KCl $1 \mathrm{M})$ (Menon, 1973), $\mathrm{pH}_{\mathrm{ox}}(\mathrm{pH}$ dari ekstrak $\mathrm{KCl} 1 \mathrm{M}$ yang telah dioksidasi secara total dengan hidrogen peroksida $30 \%$ ), $\mathrm{S}_{\mathrm{KCl}}$ (sulfur yang diekstrak dengan $\mathrm{KCl}$ ), $\mathrm{S}_{\mathrm{P}}$ (sulfur peroksida), $\mathrm{S}_{\mathrm{POS}}\left(\mathrm{S}_{\mathrm{P}}-\mathrm{S}_{\mathrm{KCI}}\right)$ (Ahern et al., 1998a); TPA (total potential acidity) TAA (total actual acidity), TSA (total sulfidic acidity), pirit (Ahern et al., 1998bc); $\mathrm{Fe}, \mathrm{Al}$ (Menon, 1973); dan $\mathrm{PO}_{4}$ (Menon, 1973; Melville, 1993).

Sebagai peubah tergantung atau peubah tidak bebas atau peubah respon dalam penelitian ini adalah produksi total tambak. Produksi total tambak merupakan total produksi udang windu dan ikan bandeng (Hanafi, 1990), sebab tambak yang terpilih semuanya melakukan budi daya secara polikultur antara udang windu dan ikan bandeng. Peubah bebas atau peubah prediktor dikelompokkan atas faktor: status pembudi daya, pengelolaan tambak, kondisi tambak, kualitas air, dan kualitas tanah. Faktor status pembudi daya tambak terdiri atas 9 peubah, faktor kondisi tambak 11 peubah, faktor pengelolaan tambak 31 peubah, faktor kualitas air 11 peubah, dan faktor kualitas tanah 17 peubah. Model persamaan regresi berganda yang diuji adalah:

$$
\underset{\text { Persamaan 1) }}{\mathrm{Y}=\mathrm{a}+\mathrm{b}_{1} \mathrm{X}_{1}+\mathrm{b}_{2} \mathrm{X}_{2}+\mathrm{b}_{3} \mathrm{X}_{3}+\ldots+\mathrm{b}_{\mathrm{i}} \mathrm{X}_{\mathrm{i}}}
$$

Statistik deskriptif digunakan untuk mengetahui gambaran umum (minimum, maksimum, rata-rata, simpangan baku) dari data yang ada. Sebagai peubah boneka pada penelitian ini adalah: tingkat pendidikan, status pemilikan lahan, pekerjaan pokok, pekerjaan sampingan, asal lahan tambak, bentuk tambak, bahan pintu air, penerapan remediasi, penerapan keduk teplok, penerapan perbaikan pematang, penerapan perbaikan pintu air, penerapan pemasangan saringan, penerapan pestisida anorganik awal, sistem ganti air, bulan penebaran, waktu penebaran, penerapan pestisida anorganik susulan, jenis penyakit, dan tekstur tanah. Koefisien korelasi ditentukan untuk mengetahui keeratan hubungan antar peubah kualitas tanah. Koefisien korelasi yang tinggi menunjukkan hubungan yang sangat erat antar peubah dan selanjutnya dipilih satu di antaranya dengan memilih peubah yang lebih mudah ditentukan di lapangan, sedangkan peubah yang tidak terpilih dihilangkan dari model regresi. Uji reliabilitas dan uji validitas dilakukan terhadap data yang diperoleh dari kuesioner. Uji DurbinWatson digunakan untuk mendeteksi adanya gejala multikolinearitas yaitu gejala korelasi antar peubah bebas. Dalam memilih persamaan regresi ganda 'terbaik' maka digunakan metode enter (Draper \& Smith, 1981). Uji $\mathrm{R}^{2}$ (koefisien determinasi yang disesuaikan) digunakan untuk mengetahui besarnya peubah bebas menjelaskan peubah tergantung. Uji F digunakan untuk menguji signifikansi model regresi dan Uji t untuk menguji signifikansi koefisien regresi dari setiap peubah bebas. Taraf signifikansi ditetapkan sebesar 0,05. Seluruh data dianalisis dengan bantuan Program Statistial Product and Service Solution (SPSS) versi 14,0.

\section{HASIL DAN BAHASAN}

Produktivitas tambak di Kabupaten Pinrang berkisar antara 100 dan $3.050 \mathrm{~kg} / \mathrm{ha} /$ musim 
dengan produksi rata-rata $499 \mathrm{~kg} / \mathrm{ha} /$ musim (Tabel 1). Produksi merupakan produksi total yaitu produksi udang windu dan ikan bandeng yang dipolikulturkan di tambak Kabupaten Pinrang. Udang windu dan ikan bandeng adalah komoditas yang dapat dipolikulturkan di tambak (Ranoemihardjo et al., 1979; Eldani \& Primavera, 1981). Kedua komoditas tersebut secara umum menuntut kondisi lingkungan yang relatif sama, tetapi menempati relung ekologi yang berbeda dalam tambak. Perbedaan habitat makanan dari kedua komoditas tersebut yang menyebabkan tidak terjadi kompetisi di antaranya (Eldani \& Primavera, 1981). Konsep dasar dari polikultur adalah jika dua atau lebih spesies ikan yang cocok dipelihara secara bersama-sama akan meningkatkan produksi (Reich, 1975 dalam Eldani \& Primavera, 1981; Shang, 1986). Dari
Persamaan 2 diperoleh nilai konstanta a sebesar 905,21 yang berarti produktivitas tambak di Kabupaten Pinrang dapat mencapai $905,21 \mathrm{~kg} / \mathrm{ha} /$ musim, dengan asumsi semua peubah bebas konstan. Produktivitas tambak tersebut masih dapat ditingkatkan seperti dijelaskan pada bagian berikut.

Pada penelitian ini dilakukan pengamatan dan pengukuran 79 peubah, ternyata hanya 37 peubah di antaranya yang secara nyata dapat digunakan untuk memprediksi produktivitas tambak di Kabupaten Pinrang. Nilai $R^{2}$ yang didapatkan adalah 0,99 yang menunjukkan bahwa $99 \%$ produktivitas tambak di Kabupaten Pinrang dapat dijelaskan oleh 37 peubah tersebut dan hanya $1 \%$ produktivitas tambak ditentukan oleh peubah lainnya. Persamaan regresi berganda yang didapatkan dalam penelitian ini adalah:

$$
\begin{aligned}
Y= & 905,21+336,78 X_{1}+0,13 X_{2}+4,01 X_{3}+130,64 X_{4}-1,47 X_{5}+56,22 X_{6} \\
& +13,79 X_{7}-4,20 X_{8}+0,73 X_{9}-3,62 X_{10}+0,01 X_{11}+2,35 X_{12}+1,99 X_{13} \\
& -0,97 X_{14}+0.25 X_{15}+102,40 X_{16}+17,51 X_{17}+116,06 X_{18}+102,34 X_{19} \\
& -4,82 X_{20}+187,09 X_{21}+487,02 X_{22}-0,01 X_{23}+36,85 X_{24}+22,44 X_{25} \\
& +254,86 X_{26}+201,35 X_{27}-229,57 X_{28}-1,71 X_{29}+12,11 X_{30}+2,00 X_{31} \\
& -715.43 X_{32}-304,50 X_{33}+3,26 X_{34}-120,69 X_{35}-133,04 X_{36}-50,10 X_{37}
\end{aligned}
$$

(Persamaan 2)

di mana:

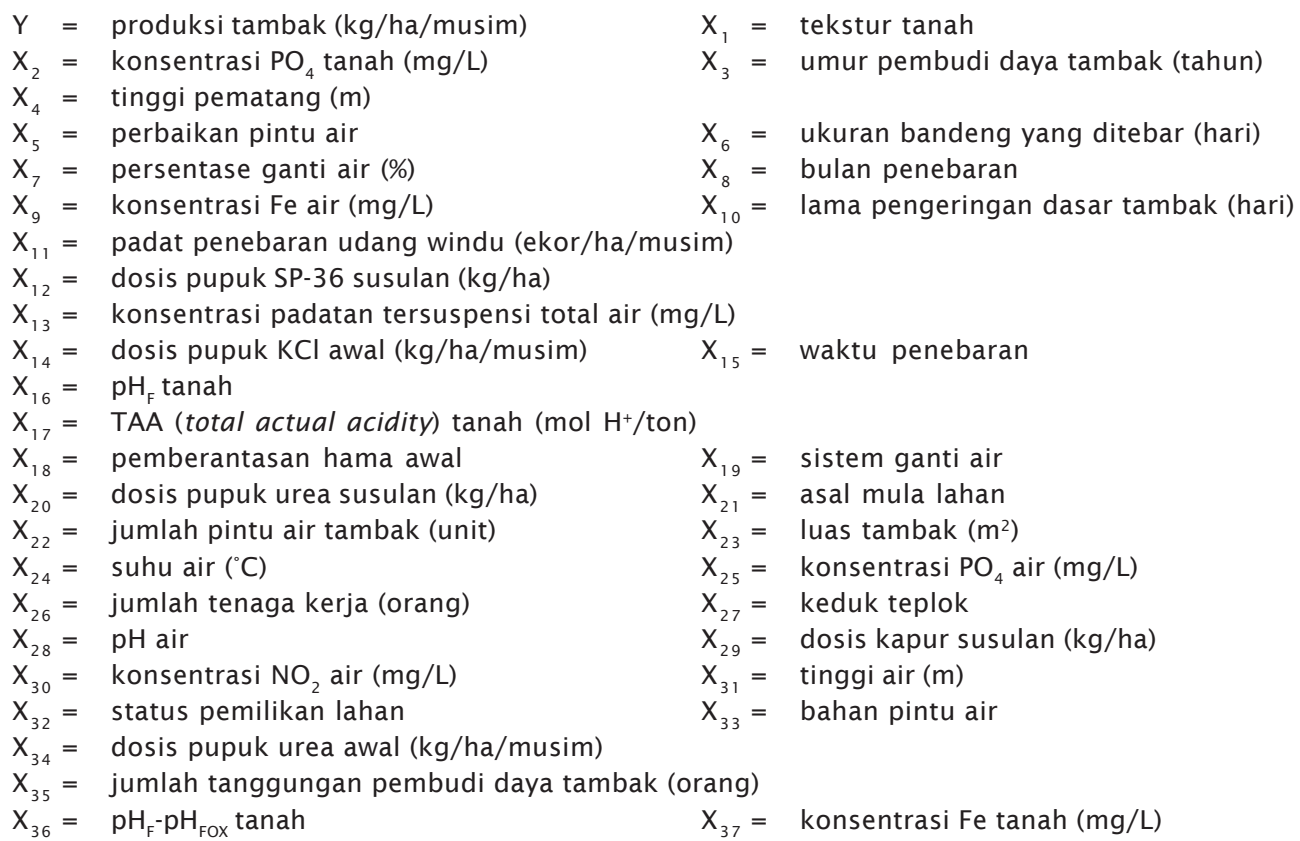




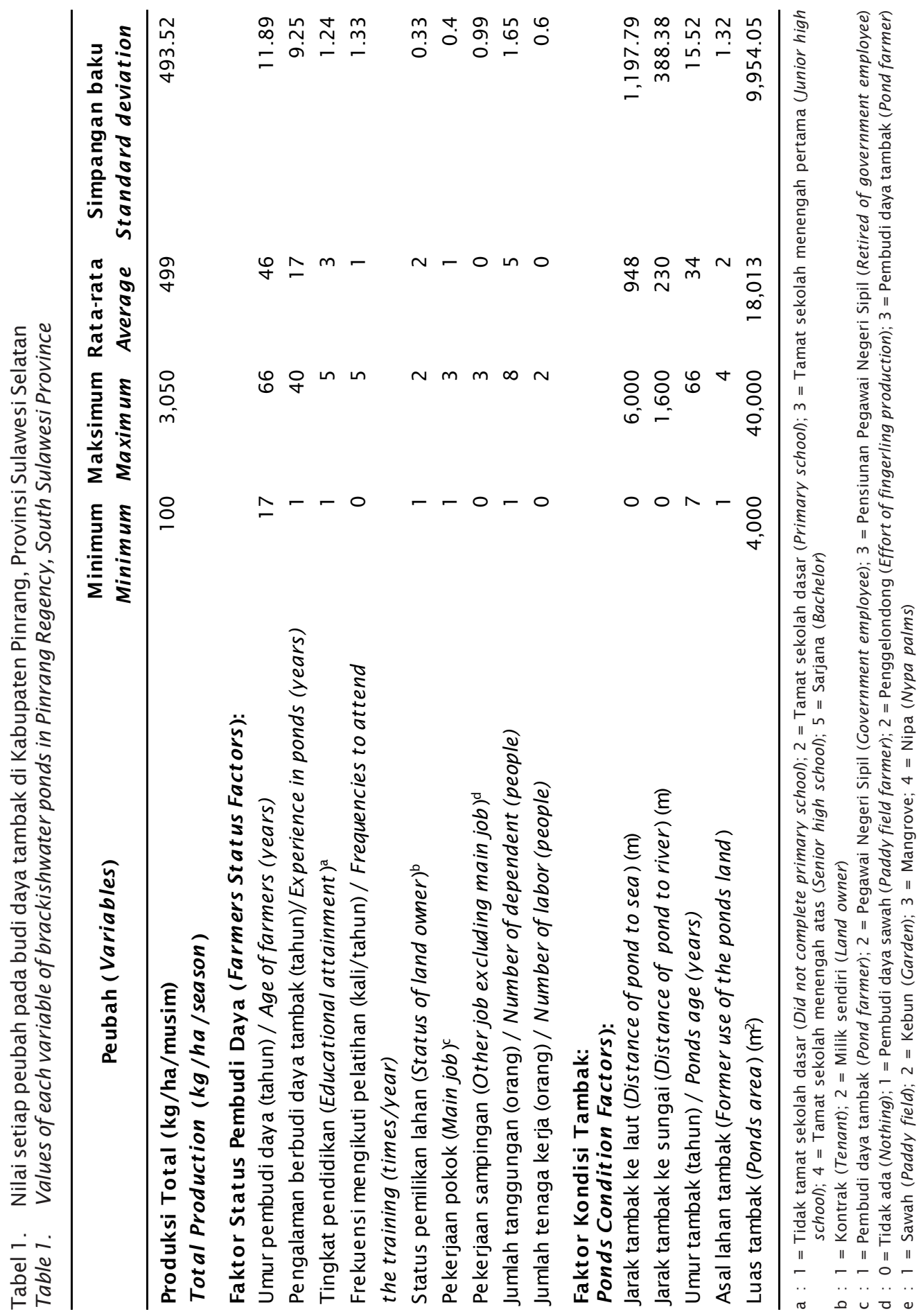




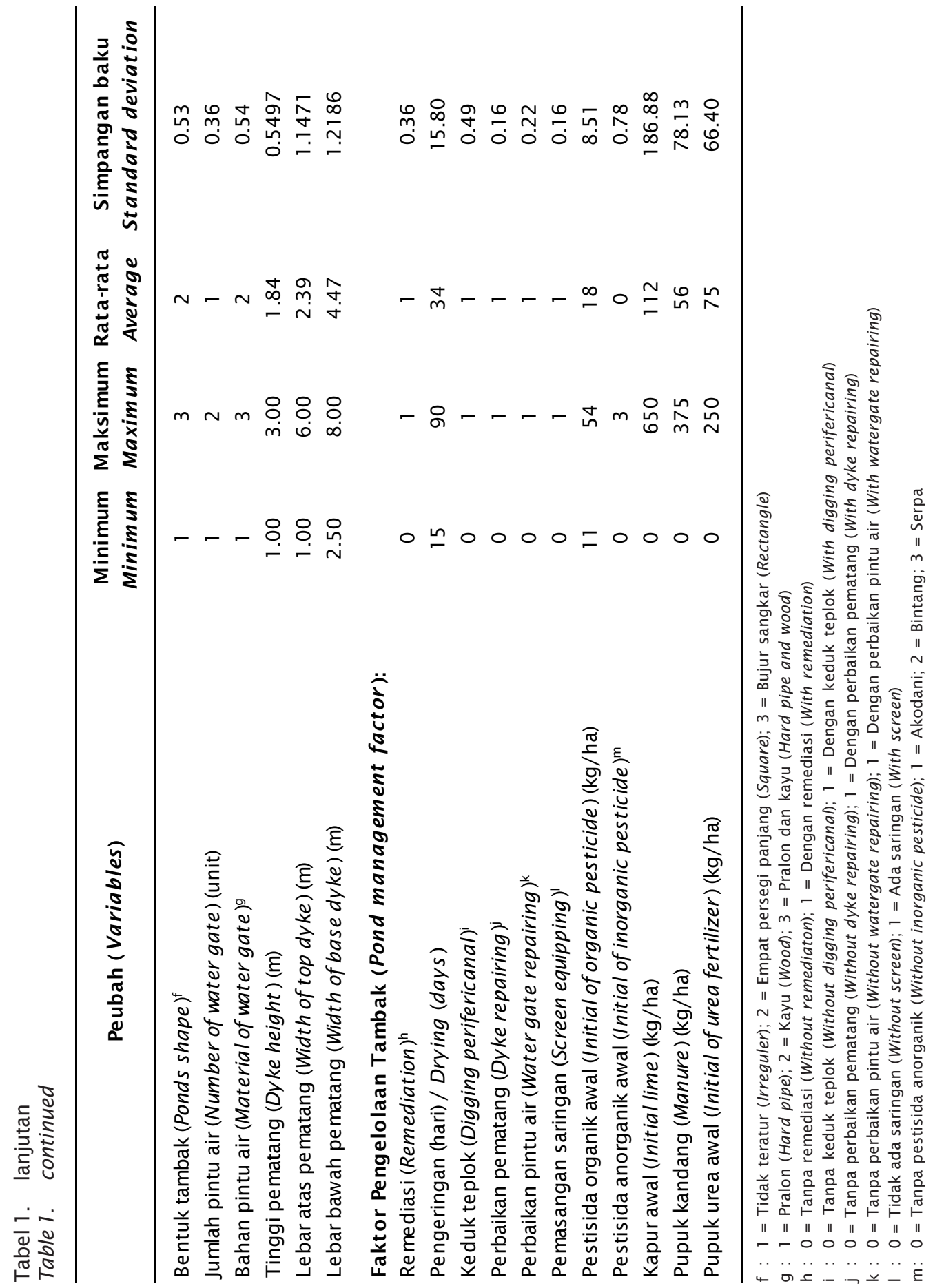




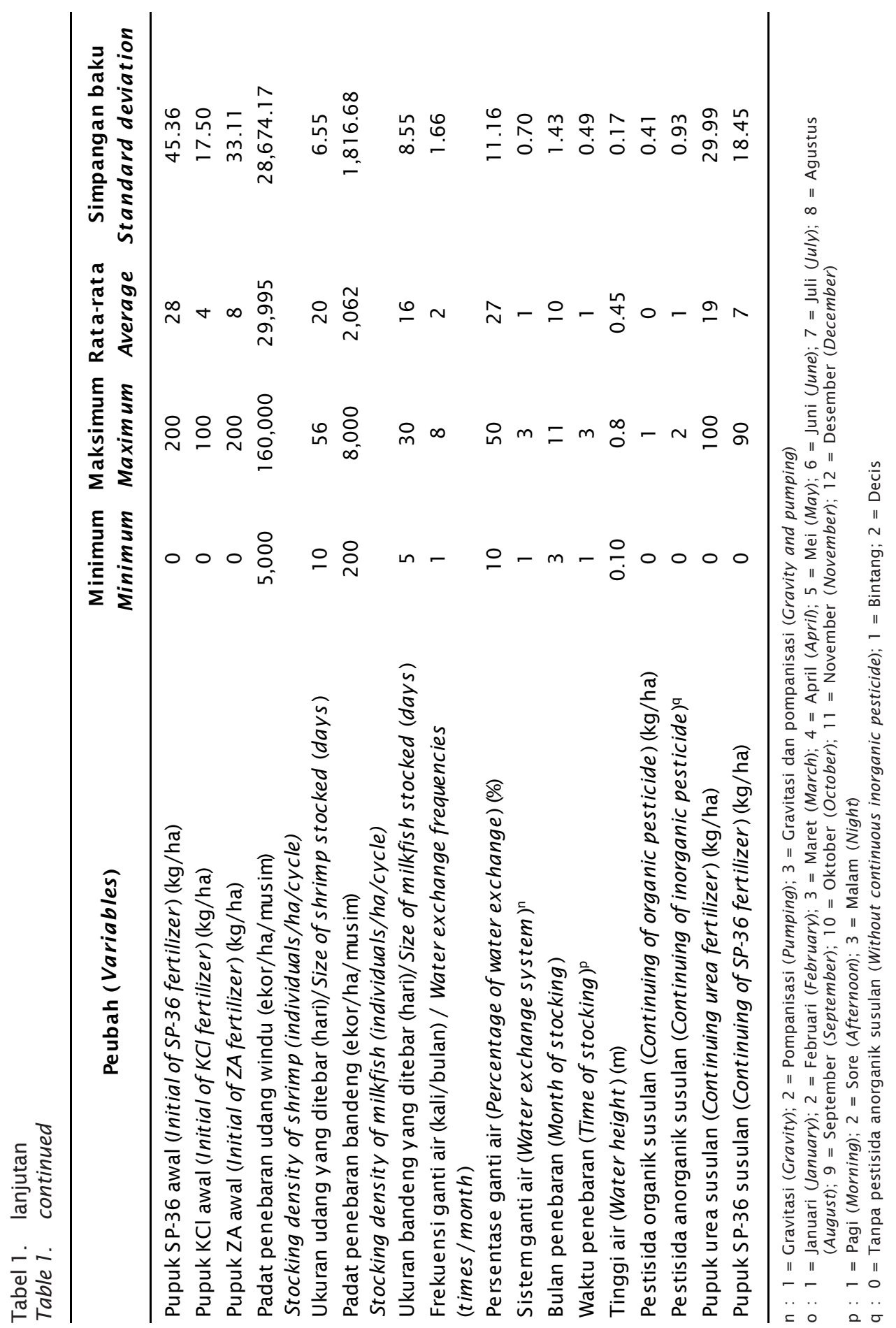




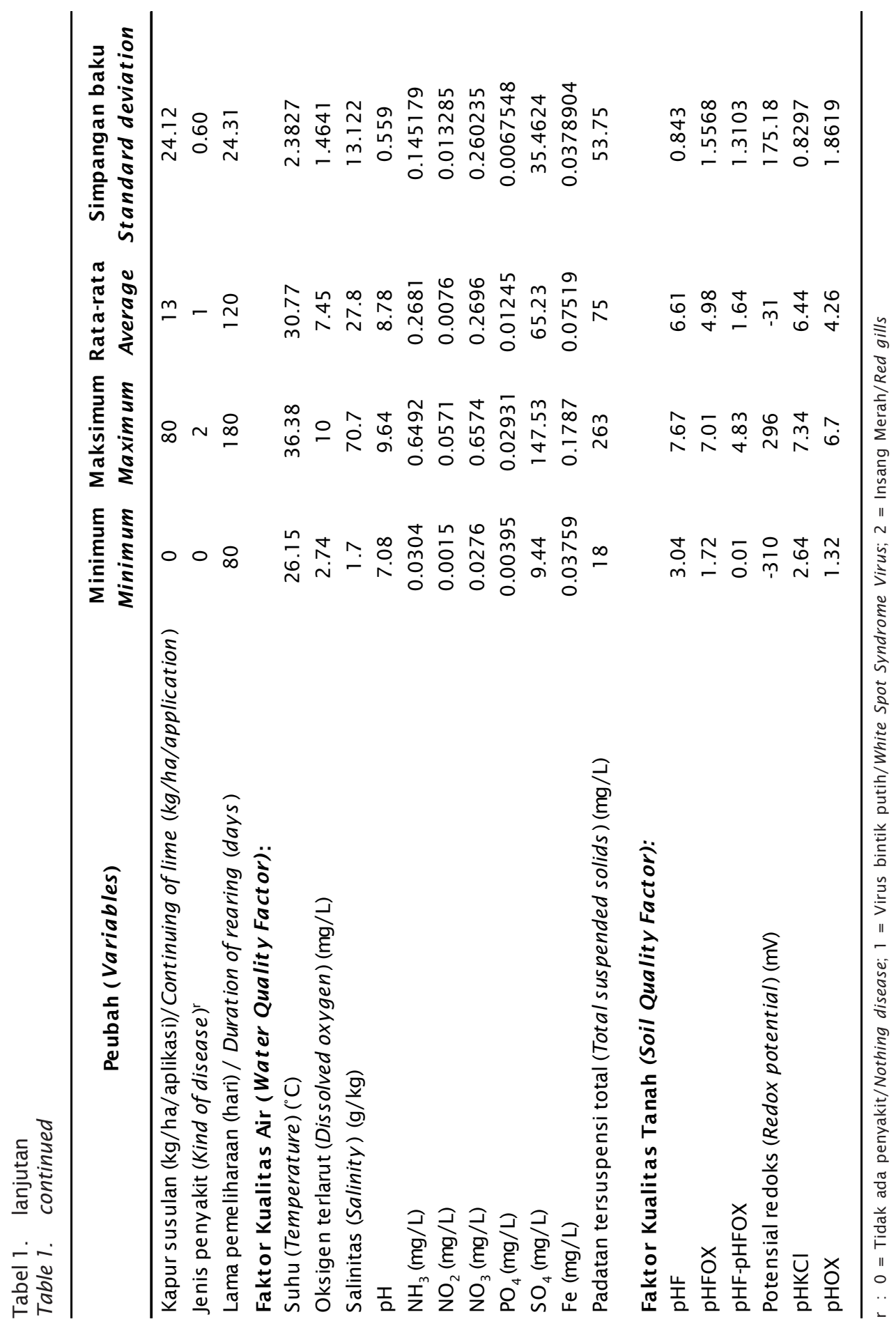




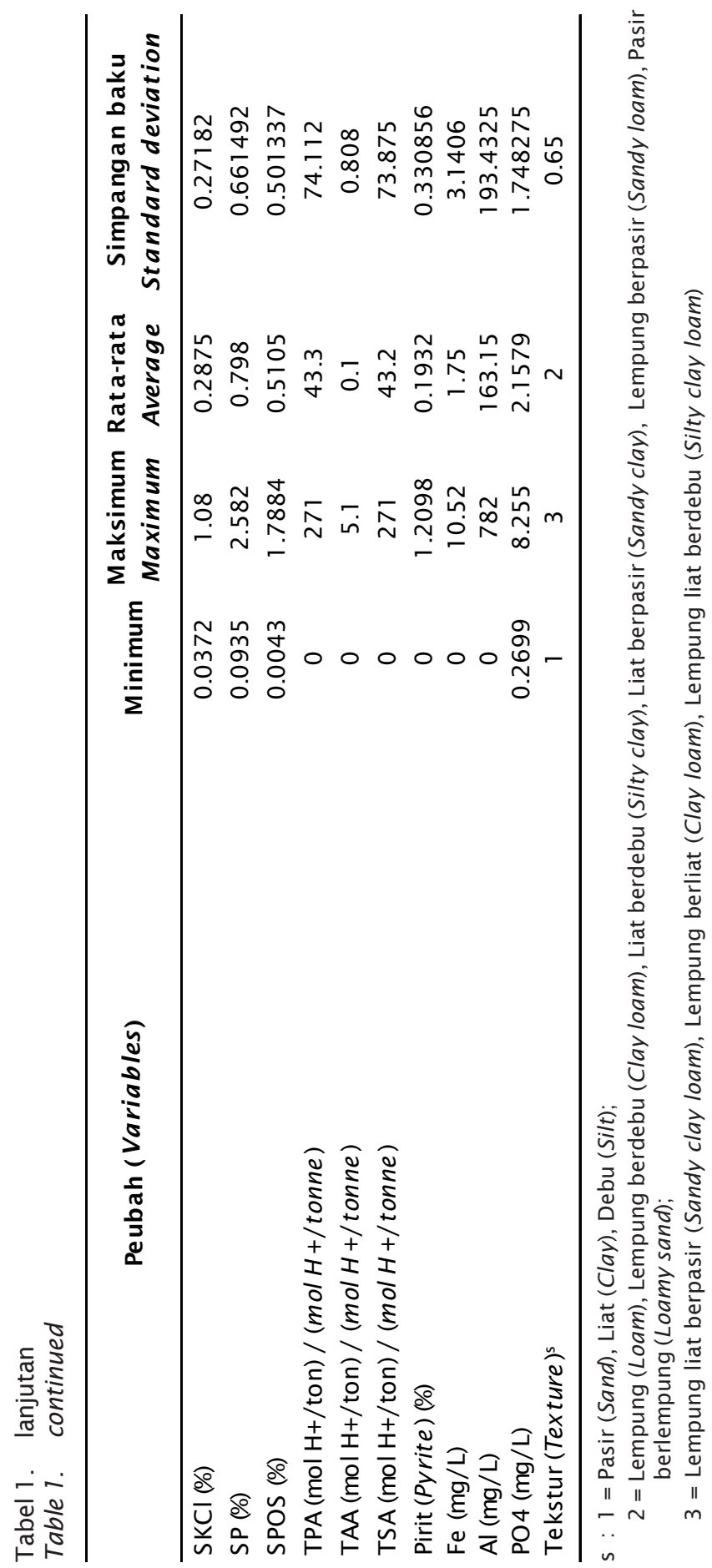


Dari sembilan peubah faktor status pembudi daya, ternyata hanya 4 peubah yang dapat mempengaruhi secara nyata produktivitas tambak di Kabupaten Pinrang yaitu: umur pembudi daya, jumlah tenaga kerja yang digunakan dalam budi daya tambak, status pemilikan lahan tambak, dan jumlah tanggungan dari pembudi daya tambak. Umur pembudi daya adalah peubah dari faktor status pembudi daya yang terbesar atau terbesar ketiga dari seluruh peubah yang berpengaruh terhadap produktivitas tambak di Kabupaten Pinrang. Peningkatan umur pembudi daya dapat meningkatkan produksi tambak, hal ini sebagai akibat dengan bertambahnya pengalaman bertambak yang diterapkan dalam pengelolaan tambaknya. Salah satu faktor yang mempengaruhi keberhasilan budi daya ikan bandeng di Taiwan adalah pengelola atau pembudi daya tambak, di mana pengalaman bertambak menjadi penting dan terlihat bahwa pengelola yang lebih tua lebih besar peluang keberhasilannya dalam bertambak (Shang, 1976; Chiang et al., 2004). Dikatakan oleh Chong et al. (1984) bahwa umur pembudi daya tambak secara jelas menunjang proses pengambilan keputusan, karena kemampuan manajerial secara umum diasumsikan sebagai fungsi bentuk-U terbalik dari umur. Dengan kata lain, kemampuan manajerial rendah pada umur muda, meningkat sesuai umur dan mencapai puncak pada umur tertentu dan selanjutnya menurun dengan meningkatnya umur. Umur termuda dari pembudi daya tambak di Kabupaten Pinrang adalah 17 tahun dan tertua adalah 66 tahun dengan rata-rata 46 tahun. Diduga dengan umur 46 tahun, kemampuan manajerial belum mencapai puncaknya sehingga peningkatan umur pembudi daya masih dapat meningkatkan kemampuan manajerial yang pada akhirnya dapat meningkatkan produktivitas tambak.

Pertambahan jumlah tenaga kerja yang digunakan dalam bertambak juga dapat menyebabkan peningkatan produksi tambak. Penambahan 1 orang tenaga kerja dapat meningkatkan produksi tambak sebanyak 255 $\mathrm{kg} / \mathrm{ha} /$ musim (tanda +) (Persamaan 2). Pada umumnya tenaga kerja pada budi daya tambak banyak digunakan pada saat persiapan tambak dan panen (Hanafi, 1990). Lebih lanjut Collier (1987) menyatakan bahwa masukan faktor produksi ke tambak yang utama adalah tenaga kerja untuk menebar benih dan memelihara serta menjaga tambak. Kegiatan pertanian termasuk budi daya tambak adalah kegiatan berat yang membutuhkan tenaga dan waktu (Sugihen, 1996). Di dalam masyarakat yang masih bertahan dengan sistem pertanian subsistem hampir semua pekerjaan di atas lahan dikerjakan sendiri oleh kepala keluarga dan atau bersama-sama anggota keluarganya, terutama pada masa puncak kegiatan, seperti pada saat persiapan lahan dan panen. Seperti dikatakan oleh Muluk \& Baily (1996) bahwa tenaga kerja di tambak yang dikelola secara ekstensif (tradisional) di Indonesia umumnya dari keluarga pembudi daya atau penyewa tambak. Penambahan jumlah tanggungan tidak memicu adanya peningkatan produktivitas tambak. Diduga, anggota keluarga yang ditanggung belum tergolong umur angkatan kerja. Sebagian penduduk usia remaja (15-20 tahun) di Kabupaten Pinrang belum bekerja (Ratnawati et al., 2002).

Pembudi daya tambak yang mengelola tambaknya sendiri memiliki produktivitas tambak yang lebih tinggi daripada pembudi daya tambak yang mengelola tambak yang dikontrak. Tanah yang disewa, produksinya diarahkan untuk sekedar memenuhi kebutuhan hidup, produktivitasnya rendah, dan teknologinya juga rendah (Sugihen, 1996). Dikatakan oleh Ratnawati et al. (2002) bahwa tingkat pendidikan pembudi daya tambak di Kabupaten Pinrang relatif rendah, namun mempunyai kemauan kerja yang cukup besar, tetapi kelangkaan modal dan rendahnya keterampilan menjadi kendala dalam peningkatan produktivitas tambak.

Dari 11 peubah faktor kondisi tambak hanya peubah asal lahan tambak, luas tambak, jumlah pintu air, bahan dari pintu air, dan tinggi pematang tambak yang berpengaruh nyata terhadap produktivitas tambak. Lahan tambak yang berasal dari mangrove dan nipa dan campuran keduanya relatif lebih tinggi dibandingkan dengan dari kebun maupun dari sawah. Hal ini mungkin terkait dengan kondisi air yang relatif lebih baik dari segi kualitas dan lebih banyak dari segi kuantitas pada tambak yang dibangun di daerah bekas mangrove dan nipa. Tambak yang berasal dari sawah maupun kebun sangat sulit untuk mendapatkan sumber air laut atau payau. Semakin luas tambak yang dikelola juga dapat menurunkan produktivitas tambak. Hal ini dapat dimengerti bahwa semakin luas tambak yang dikelola oleh seorang pembudi daya tambak, maka semakin berkurang tingkat pengelolaan yang dilakukan karena pembudi daya tambak dibatasi oleh tenaga dan waktu serta kemungkinan dana. 
Dengan ukuran tambak yang lebih kecil cenderung pembudi daya tambak memaksimalkan penggunaan sumber daya lahan tersebut untuk memperoleh produksi rumput laut (Gracilaria verrucosa) yang lebih banyak dibandingkan dengan tambak yang lebih luas di Kabupaten Luwu (Mustafa \& Ratnawati, 2005). Islam et al. (2005) dan Milstein et al. (2005) menyatakan bahwa tambak yang lebih kecil akan lebih mudah dikelola dan produktivitasnya untuk udang windu lebih tinggi daripada yang berukuran lebih luas di Banglades. Penambahan pintu air juga berdampak pada peningkatan produksi tambak. Pada tambak yang memiliki 2 unit pintu air memungkinkan pemasukan air dan pengeluaran airnya berbeda sehingga kualitas air dalam tambak dapat lebih baik yang berdampak pada produksi yang lebih tinggi. Dari Persamaan 2 terlihat bahwa nilai koefisien regresi b untuk jumlah pintu air $\left(b_{22}\right)$ adalah + 487,02 yang berarti penambahan 1 unit pintu air yang diikuti dengan pemisahan saluran pemasukan dan pengeluaran akan meningkatkan $(\operatorname{tanda}+$ ) produktivitas tambak. Perubahan bahan pintu air dari kayu menjadi pipa paralon dapat meningkatkan produktivitas tambak. Pipa paralon umumnya digunakan pada tambak yang dikelola secara semi intensif (madya), sehingga produksinya lebih tinggi daripada tambak yang dikelola secara sederhana yang menggunakan pintu kayu. Penambahan tinggi pematang tambak juga secara nyata dapat meningkatkan produktivitas tambak. Dengan bertambahnya tinggi pematang diharapkan tinggi air dalam tambak juga lebih tinggi yang berdampak positif pada budi daya udang windu. Hal ini didukung dengan hasil yang ditunjukkan bahwa peningkatan tinggi air dalam tambak juga meningkatkan produktivitas tambak. Tinggi air tambak di Kabupaten Pinrang berkisar dari 0,10 sampai $0,80 \mathrm{~m}$ dengan ratarata $0,45 \mathrm{~m}$. Rata-rata tinggi air dalam tambak tergolong rendah untuk budi daya udang windu, seperti dikatakan oleh Chiang et al. (1989) bahwa kedalaman optimum untuk udang windu pada saat penebaran adalah $0,30--0,60$ $\mathrm{m}$ dan selanjutnya kedalaman air meningkat mencapai 1,00--1,20 m. Sebaliknya, kedalaman air tambak tersebut tidak bermasalah dalam budi daya ikan bandeng, sebab ikan bandeng dapat dipelihara pada tambak dangkal $(0,30--$ $0,40 \mathrm{~m}$ ) (Padlan et al., 1975; Chiang et al., 2004).

Di antara 31 peubah pengelolaan tambak, ada 16 peubah di antaranya yang memberikan pengaruh yang nyata terhadap produksi tambak. Peubah tersebut meliputi: pengeringan dasar tanah tambak, keduk teplok, perbaikan pintu air, pemberantasan hama awal, pemupukan urea awal, pemupukan $\mathrm{KCl}$ awal, padat penebaran udang windu, ukuran bandeng yang ditebar, bulan penebaran, waktu penebaran, tinggi air, persentase ganti air, sistem ganti air, pemupukan urea susulan, pemupukan SP-36 susulan, dan pengapuran susulan. Pengeringan tambak yang dilakukan pembudi daya tambak relatif lama, sampai 90 hari dalam kondisi cuaca cerah yang berdampak pada perubahan struktur tanah yang menjadi berdebu. Seperti dikatakan oleh Stevenson (1982) dalam Meagaung et al. (2000) bahwa pengeringan tanah dalam waktu lama akan mempercepat rusaknya struktur tanah, sehingga mikroorganisme tanah tidak dapat melakukan proses dekomposisi bahan organik secara optimum. Sebagai akibatnya, kelekap yang tumbuh pada saat budi daya banyak yang terlepas dan membusuk yang dapat menurunkan kualitas air. Telah dilaporkan oleh Meagaung et al. (2000) bahwa lama pengeringan tambak yang dilakukan pada tambak intensif (maju) di Sulawesi Selatan adalah 7--210 hari. Dari Persamaan 2 terlihat bahwa nilai koefisien regresi b untuk lama pengeringan $\left(b_{10}\right)$ adalah $-3,62$ yang berarti penambahan 1 hari lama pengeringan dapat menurunkan (tanda -) produktivitas tambak sebesar 3,62 kg/ha/musim. Keduk teplok dan perbaikan pintu air dapat meningkatkan produksi tambak. Hal ini dapat dimengerti bahwa dengan keduk teplok yang berarti mengangkat tanah permukaan terutama di bagian saluran keliling yang banyak mengandung zat toksik seperti $\mathrm{H}_{2} \mathrm{~S}$ dan $\mathrm{CH}_{4}$ sehingga berdampak pada kondisi tambak yang lebih baik. Perbaikan pintu air dapat mempertahankan tinggi air dalam tambak. Pada tahun 1980-an, salah satu kegiatan rutin yang dilakukan oleh pembudi daya tambak di Pulau Jawa adalah perbaikan pintu air pada saat persiapan tambak, sebab bahan pintu airnya terbuat dari kayu pohon kelapa yang bentuknya memungkinkan terjadinya kebocoran (Collier, 1987).

Pemberantasan hama awal dengan menggunakan pestisida organik yaitu saponin secara nyata berpengaruh terhadap produktivitas tambak. Peningkatan dosis saponin juga dapat meningkatkan produktivitas tambak. Ada pembudi daya yang hanya mengaplikasikan saponin sebanyak $11 \mathrm{~kg} / \mathrm{ha}$ dan hanya 
diaplikasikan pada saluran keliling, sehingga peluang munculnya hama seperti ikan mujair cukup besar yang pada akhirnya menjadi penyaing bagi organisme akuatik yang dipelihara.

Tambak di Kabupaten Pinrang pada umumnya dapat digunakan untuk budi daya tambak 2 kali/tahun. Pembudi daya tambak menebar pada bulan Oktober dan November untuk penebaran pertama dan pada bulan Maret dan April untuk penebaran kedua. Namun demikian, penebaran yang banyak dilakukan yaitu pada bulan Oktober dan November. Penebaran pertama tersebut, memungkinkan diperoleh produksi yang lebih baik daripada penebaran kedua, terutama tambak-tambak yang tidak memiliki sumber air tawar untuk menurunkan salinitas air tambak. Selain itu, curah hujan yang sangat rendah sebelum penebaran pertama ini mengakibatkan pembudi daya tambak dapat melakukan persiapan tambak yang lebih sempurna. Curah hujan yang rendah di Kabupaten Pinrang terjadi pada Agustus dan September, sehingga merupakan waktu yang baik untuk pengeringan tambak, pemberantasan hama, perbaikan pematang, dan keduk teplok.

Aplikasi pupuk urea sebagai pupuk dasar pada saat persiapan tambak dan aplikasi urea dan SP-36 sebagai pupuk susulan dapat meningkatkan produktivitas tambak. Urea adalah pupuk yang umum digunakan oleh pembudi daya tambak sebagai sumber nitrogen. Bentuk nitrogen yang dapat dimanfaatkan secara langsung oleh tumbuhan akuatik adalah nitrat $\left(\mathrm{NO}_{3}\right)$, amonium $\left(\mathrm{NH}_{4}\right)$, dan gas nitrogen $\left(\mathrm{N}_{2}\right)$. SP-36 adalah pupuk yang mengandung fosfat. Fosfat merupakan unsur yang esensial bagi tumbuhan tingkat tinggi dan alga, sehingga unsur ini menjadi faktor pembatas bagi tumbuhan dan alga akuatik serta sangat mempengaruhi tingkat produktivitas perairan. Jones \& Bachmann (1976) dalam Davis \& (Cornwell, 1991) mengemukakan korelasi positif antara kadar fosfat dengan klorofil a. Tidak seperti dengan aplikasi pupuk urea dan SP-36, aplikasi $\mathrm{KCl}$ pada saat persiapan tambak dapat menurunkan produktivitas tambak. Pupuk KCl merupakan sumber unsur hara K (kalium) dan $\mathrm{Cl}$ (khlor). Unsur hara K merupakan unsur hara makro yaitu unsur hara yang dibutuhkan dalam jumlah banyak oleh tanaman, sedangkan $\mathrm{Cl}$ adalah unsur hara mikro yang dibutuhkan oleh sistem kehidupan tanaman dalam jumlah sedikit. Namun demikian, kalium tidak banyak diberikan dalam budi daya tambak karena sudah ada suplai dari air laut yang mengandung $\mathrm{K}$ sebesar $420 \mathrm{mg} / \mathrm{L}$ pada salinitas 35 ppt (Riley \& Chester, 1971). Pupuk yang mengandung $\mathrm{K}$ jarang digunakan di tambak, karena secara normal sudah cukup di lingkungan tambak (PCARR, 1976 dalam Chong et al., 1984). Air laut mengandung $\mathrm{Cl}$ sekitar 19.300 mg/L (McNeely et al., 1979).

Pengapuran susulan yang diaplikasi oleh pembudi daya tambak di Kabupaten Pinrang maksimum 80 kg/ha/aplikasi. Namun demikian, karena $\mathrm{pH}$ air tambak cukup tinggi yaitu ratarata 8,78 (Tabel 1 ) dan inilah yang menyebabkan pengaruh negatif dari pengapuran susulan terhadap produktivitas tambak. Kemungkinan lain adalah penggunaan kapur bakar dalam pengapuran susulan yang juga dapat membahayakan kehidupan organisme yang sedang dibudidayakan.

Nilai koefisien regresi b untuk persentasi ganti air $\left(b_{7}\right)$ adalah $+13,79$ (Persamaan 2$)$. Hal ini menunjukkan bahwa peningkatan $1 \%$ dari persentasi ganti air tambak dapat meningkatkan produktivitas tambak 13,79 kg/ha/musim. Persentasi ganti air di tambak Kabupaten Pinrang sebesar $27 \%$ yang dilakukan pada setiap 15 hari atau setiap pasang tinggi. Telah dilaporkan oleh Fattah \& Busaeri (2003) bahwa pembudi daya tambak di Dusun Kae, Desa Tasiwalie, Kecamatan Suppa, Kabupaten Pinrang hanya melakukan satu kali pergantian air selama satu musim, karena saluran yang tersumbat oleh sedimentasi pada bulan Desember sampai April. Pergantian air berarti membuang air yang kualitasnya sudah menurun dan memasukkan air baru yang lebih segar dan tentunya lebih berkualitas.

Penambahan padat penebaran udang windu dan ukuran bandeng yang ditebar masih dapat meningkatkan produksi tambak. Padat penebaran udang windu dan ikan bandeng yang diaplikasikan oleh pembudi daya tambak adalah rata-rata 29.995 dan 2.062 ekor/ha/ musim. Dalam hal ini, pembudi daya tambak yang menebar udang windu dengan padat penebaran kurang dari 29.995 ekor/ha/musim masih dapat meningkatkan padat penebarannya. Produksi tertinggi dari udang windu dan ikan bandeng diperoleh pada padat penebaran udang windu dan ikan bandeng berturut-turut 8.000 dan 2.000 ekor/ha yang dipolikultur selama 4 bulan tanpa pemberian pakan buatan (Eldani \& Primavera, 1981). Tingginya padat penebaran udang windu yang diaplikasikan oleh pembudi daya tambak di Kabupaten Pinrang, karena disertai dengan 
pemberian pakan tambahan. Di Asia, polikultur biasa diterapkan pada sistem budi daya semiintensif, tetapi monokultur masih dominan (Ling et al., 2001).

Suhu air tambak di Kabupaten Pinrang relatif tidak terlalu tinggi, rata-rata $30,77^{\circ} \mathrm{C}$ sebagai akibatnya peningkatan suhu air masih dapat meningkatkan produksi tambak (Persamaan 2). Secara umum, suhu air antara $26^{\circ} \mathrm{C}$ dan $32^{\circ} \mathrm{C}$ sesuai untuk budi daya udang dan suhu antara $29^{\circ} \mathrm{C}$ dan $30^{\circ} \mathrm{C}$ adalah suhu optimum untuk udang windu (Poernomo, 1988). Suhu air untuk budi daya bandeng di tambak berkisar antara $20^{\circ} \mathrm{C}-43^{\circ} \mathrm{C}$ (Lin, 1969; Villaluz \& Unggui, 1983).

Sebaliknya $\mathrm{pH}$ air tambak cukup tinggi dengan rata-rata 8,78 dan maksimum 9,64. Sebagai akibatnya peningkatan $\mathrm{pH}$ air tambak dapat menurunkan produksi. Hal ini juga terlihat pada hasil yang memperlihatkan bahwa pengapuran susulan dapat menurunkan produksi tambak. Pada $\mathrm{pH}$ air antara 4,5 dan 6,5 dapat menyebabkan pertumbuhan yang lambat dan konsumsi pakan yang rendah dari udang windu (Tsai, 1989). Pertumbuhan udang akan terhambat pada $\mathrm{pH}$ air kurang dari 6,4 (Wickins, 1984) atau lebih besar dari 8,9 (Furukawa, 1973). Peningkatan konsentrasi $\mathrm{PO}_{4}$ dalam air dapat meningkatkan produksi tambak. Fosfat merupakan unsur penting bagi semua aspek kehidupan terutama dalam transformasi energi metabolik (Kuhl, 1974). Unsur P juga merupakan penyusun ikatan pirofosfat dari ATP (adenosine trifosfat) yang kaya energi dan merupakan bahan bakar untuk semua kegiatan biokimia di dalam sel hidup serta merupakan penyusun sel yang penting (Noggle \& Fritz, 1986 dalam Andarias, 1991).

Fe termasuk unsur yang esensial bagi makhluk hidup. Pada tumbuhan, termasuk alga, Fe berperan sebagai penyusun sitokrom dan klorofil. Namun demikian, konsentrasi Fe dalam air yang berlebihan dapat menghambat fiksasi unsur lainnya. Kisaran konsentrasi $\mathrm{Fe}$ air tambak di Kabupaten Pinrang dari 0,03759 sampai $0,17870 \mathrm{mg} / \mathrm{L}$ dengan rata-rata $0,07519 \mathrm{mg} / \mathrm{L}$. Konsentrasi Fe air yang lebih tinggi dari 1,0 mg/L dianggap membahayakan kehidupan organisme akuatik (Moore, 1991). Oleh karena itu, peningkatan konsentrasi Fe air sampai konsentrasi tertentu masih dapat meningkatkan produktivitas tambak di Kabupaten Pinrang (Persamaan 2). Konsentrasi Fe pada perairan alami berkisar antara 0,05 dan 0,20 mg/L (Boyd, 1990), konsentrasi Fe ini relatif sama dengan konsentrasi Fe air tambak di Kabupaten Pinrang.

Padatan tersuspensi total terdiri atas lumpur dan pasir halus serta jasad renik, yang terutama disebabkan oleh kikisan tanah atau erosi yang terbawa ke badan air. Dalam hal ini, peningkatan konsentrasi padatan tersuspensi berdampak negatif terhadap budi daya tambak. Rata-rata konsentrasi padatan tersuspensi total air tambak di Kabupaten Pinrang sebesar 75 mg/L (Tabel 1). Konsentrasi padatan tersuspensi total ini tergolong masih sedikit pengaruh negatifnya terhadap kepentingan perikanan berdasarkan kriteria dari Alabaster \& Lloyd (1980). Namun demikian, sekitar 30\% dari contoh air tambak di Kabupaten Pinrang mengandung padatan tersuspensi total antara 81 dan 263 mg/L yang tergolong kurang baik bagi kepentingan perikanan menurut kriteria Alabaster \& Lloyd (1980). Nampaknya, reservoir untuk menurunkan konsentrasi padatan tersuspensi total air tambak perlu mendapat perhatian Kabupaten Pinrang.

Dari 17 peubah kualitas tanah, ternyata hanya 6 peubah di antaranya yang memberikan pengaruh yang nyata terhadap produksi tambak di Kabupaten Pinrang dengan urutan dari yang paling besar pengaruhnya yaitu: tekstur, $\mathrm{PO}_{4}, \mathrm{pH}_{\mathrm{F}}, \mathrm{TAA}, \mathrm{pH}_{\mathrm{F}}-\mathrm{pH}_{\mathrm{FOX}}, \mathrm{n}$ Fe tanah. Tekstur tanah adalah peubah yang paling besar pengaruhnya dalam menentukan produktivitas tambak. Pada tanah tambak yang didominasi oleh tekstur tanah yang lebih halus cenderung produksinya lebih tinggi daripada tanah yang bertekstur kasar. Tekstur tanah tambak sangat terkait dengan proses erosi, dan sedimentasi, kestabilan pematang, penyerapan ke samping dan kesesuaian habitat dasar tambak (Boyd, 1995). Tanah tambak sering dijumpai bertekstur halus dengan kandungan liat minimum 20\%-0\% untuk menahan peresapan ke samping (Boyd, 1995). Tambak dengan tanah pematang bertekstur lebih halus akan lebih stabil dan proses erosi lebih kecil daripada tambak dengan tanah pematang bertekstur lebih kasar. Juga ada kecenderungan kelimpahan kelekap yang lebih tinggi pada tanah dasar tambak yang bertekstur lebih halus daripada yang bertekstur lebih kasar (ASEAN, 1978). Tekstur tanah yang baik untuk tambak adalah: liat, lempung berliat, lempung liat berdebu, lempung berdebu, lempung,dan lempung liat berpasir (Ilyas et al., 1987).

Fosfat adalah unsur esensial sebagai sumber energi pada banyak bentuk kehidup- 
an. Pada sistem akuatik, fosfat juga merupakan unsur penting karena merupakan unsur esensial untuk produksi primer (Boyd, 1995). Pengalaman di bidang akuakultur juga menunjukkan bahwa penambahan fosfat dapat meningkatkan produksi ikan di tambak (Hickling, 1971). Ketersediaan fosfat lebih besar $60 \mathrm{mg} / \mathrm{L}$ dalam tanah tambak dapat digolongkan sebagai slight atau tergolong baik dengan faktor pembatas yang sangat mudah diatasi (Karthik et al., 2005). Konsentrasi fosfat tanah di tambak Kabupaten Pinrang berkisar antara 0,2699 dan 8,2550 mg/ $\mathrm{L}$ dengan rata-rata $2,1579 \mathrm{mg} / \mathrm{L}$. Dalam hal ini, konsentrasi fosfat tanah di tambak Kabupaten Pinrang tergolong rendah, sehingga sangat dibutuhkan pemupukan yang mengandung fosfat seperti SP-36.

Dari Tabel 1 terlihat bahwa $\mathrm{pH}_{\mathrm{F}}$ tanah tambak di Kabupaten Pinrang berkisar antara 3,04 dan 7,67 dengan rata-rata 6,61. Peningkatan $\mathrm{pH}_{\mathrm{F}}$ tanah dapat meningkatkan produksi tambak di Kabupaten Pinrang. Tanah tambak dengan $\mathrm{pH}$ antara 6,5 dan 8,5 digolongkan oleh Karthik et al. (2005) sebagai slight karena nilai pH tanah tersebut tergolong baik dan pembatasnya sangat mudah sekali diatasi. Selanjutnya llyas et al. (1987) menyatakan bahwa $\mathrm{pH}$ tanah optimum untuk budi daya udang windu di tambak adalah antara 7,5 dan 8,3. Nilai $\mathrm{pH}_{\mathrm{F}}-\mathrm{pH}_{\mathrm{FOx}}$ menunjukkan bahwa semakin besar nilai ini menunjukkan bahwa potensi kemasaman tanah tambak semakin besar. Dengan penurunan nilai $\mathrm{pH}_{\mathrm{F}}-\mathrm{pH}_{\mathrm{FOx}}$ dapat juga meningkatkan produksi tambak sebab potensi kemasaman tanah yang berkurang.

Konsentrasi Fe tanah di tambak Kabupaten Pinrang dari tidak terdeteksi sampai 10,52 mg/ $\mathrm{L}$ dengan rata-rata 1,75 mg/L. Konsentrasi Fe tanah ini sangat rendah jika dibandingkan dengan konsentrasi rata-rata Fe tanah dari tanah sulfat masam yang berlokasi di Kecamatan Walenrang, Kabupaten Luwu, Provinsi Sulawesi Selatan yaitu sebesar 3.826 $\mathrm{mg} / \mathrm{L}$ (Mustafa, 2006). Fe tanah di tambak Kabupaten Pinrang diduga berasal dari pirit $\left(\mathrm{FeS}_{2}\right)$ yang dijumpai pada tempat tertentu saja dalam konsentrasi yang rendah.

\section{KESIMPULAN DAN SARAN}

Rata-rata produktivitas tambak di Kabupaten Pinrang sebesar 492 kg/ha/musim. Produktivitas tambak masih dapat ditingkatkan melalui penambahan tenaga kerja dan pemisahan saluran pemasukan dan pengeluaran air serta penambahan tinggi pematang agar tinggi air juga dapat ditingkatkan. Aplikasi pupuk urea pada saat persiapan tambak dan aplikasi urea dan SP-36 sebagai pupuk susulan dapat meningkatkan produktivitas tambak, sebaliknya aplikasi $\mathrm{KCl}$ pada saat persiapan tambak dapat menurunkan produktivitas tambak. Pengurangan kapur susulan dan peningkatan pupuk yang mengandung fosfat dapat meningkatkan produktivitas tambak.

\section{UCAPAN TERIMA KASIH}

Penulis mengucapkan banyak terima kasih kepada Muhammad Arnold dan Darsono atas bantuannya di lapangan, Rosiana Sabang, Rahmiyah, dan Kamariah atas bantuannya dalam analisis kualitas tanah serta Sutrisyani, Andi Sahrijanna, dan Kurnia atas bantuannya dalam analisis kualitas air. Juga diucapkan terima kasih pada Projek ACIAR FIS/2002/076 (Land Capability Assessment and Classification for Sustainable Pond-based, Aquaculture Systems) atas penyediaan berbagai fasilitas penelitian.

\section{DAFTAR PUSTAKA}

Ahern, C.R. and Blunden, B. 1998. Designing a soil sampling and analysis program. In: Ahern, C. R., Blunden, B. and Stone Y. (Eds.), Acid Sulfate Soils Laboratory Methods Guidelines. Acid Sulfate Soil Management Advisory Committee, Wollongbar, NSW. p. 2.1-2.6.

Ahern, C.R., McElnea, A. and Baker, D.E. 1998a. Acid neutralizing capacity methods. In: Ahern, C.R., Blunden, B., and Stone Y. (Eds.), Acid Sulfate Soils Laboratory Methods Guidelines. Acid Sulfate Soil Management Advisory Committee, Wollongbar, NSW. p. 6.1-6.4.

Ahern, C.R., McElnea, A. and Baker, D.E. 1998b. Peroxide oxidation combined acidity and sulfate. In: Ahern, C. R., Blunden, B., and Stone Y. (Eds.), Acid Sulfate Soils Laboratory Methods Guidelines. Acid Sulfate Soil Management Advisory Committee, Wollongbar, NSW. p. 4.1-4.17.

Ahern, C.R., McElnea, A. and Baker, D.E. 1998c. Total oxidisable sulfur. In: Ahern, C.R., Blunden, B., and Stone Y. (Eds.), Acid Sulfate Soils Laboratory Methods Guidelines. Acid Sulfate Soil Management Advisory Committee, Wollongbar, NSW. p. 5.1-5.7.

Ahern, C.R. and G.E. Rayment. 1998. Codes for acid sulfate soils analytical methods. In: 
Ahern, C.R., B. Blunden, and Y. Stone (Eds.), Acid Sulfate Soils Laboratory Methods Guidelines. Acid Sulfate Soil Management Advisory Committee, Wollongbar, NSW. p. 3.1-3.5.

Alabaster, J.S. and Lloyd, R. 1980. Water Quality Criteria for Fresh Water Fish. Buttersworth Inc., Boston. 361 pp.

Andarias, I. 1991. Pengaruh Pupuk Urea dan TSP terhadap Produksi Klekap. Disertasi. Fakultas Pascasarjana, Institut Pertanian Bogor, Bogor. $155 \mathrm{pp}$.

Anonim. 2005. Laporan Statistik Perikanan Sulawesi Selatan 2005. Dinas Perikanan dan Kelautan Provinsi Sulawesi Selatan, Makassar. 261 pp.

Anonim. 2006. Statistik Perikanan Budidaya Indonesia 2005. Direktorat Jenderal Perikanan Budidaya, Jakarta. $116 \mathrm{pp}$.

APHA (American Public Health Association). 1998. Standard Methods for Examination of Water and Wastewater. Twentieth Edition. APHA-AWWA-WEF, Washington, DC. $1,185 \mathrm{pp}$.

ASEAN (Association of Southeast Asian Nations). 1978. Manual on Pond Culture of Penaeid Shrimp. ASEAN National Coordinating Agency of the Philippines, Manila. $132 \mathrm{pp}$.

Boyd, C.E. 1990. Water Quality in Ponds for Aquaculture. Fourth printing. Auburn University, Alabama. $454 \mathrm{pp}$.

Boyd, C.E. 1995. Bottom Soil, Sediment, and Pond Aquaculture. Chapman and Hall, New York. 348 pp.

Chiang, F.-S., Sun, C.-H., and Yu, J.-M. 2004. Technical efficiency analysis of milkfish (Chanos chanos) production in Taiwan- an application of the stochastic frontier production function. Aquaculture. 230: 99-116.

Chiang, P.D.-M., Kuo, C.-M., and Liu, C.-F. 1989. Pond preparation for shrimp growout. In: Akiyama, D.M. (Eds.), Proceedings of the Southeast Asia Shrimp Farm Management Workshop. American Soybean Association, Singapore. p. 48--55.

Chong, K.-C., Lizarondo, M.S., dela Cruz, Z.S., Guerrero, C.V., and Smith, I.R. 1984. Milkfish Production Dualism in the Philippines: A Multisiplinary Perspective on Continuous Low Yields and Constraints to Aquaculture Development. Food and Agriculture Organization of the United Nations, Rome; Bureau of Agricultural Economics, Quezon City; Bureau of Fisheries and Aquatic Re- sources, Quezon City; International Center for Living Aquatic Resources Management, Manila. 70 pp.

Collier, W.L. 1987. Budidaya ikan dan perikanan rakyat. Dalam: Marahudin F. dan Smith, I.R. (Eds.), Ekonomi Perikanan. Yayasan Obor Indonesia dan Penerbit PT Gramedia, Jakarta. p. 281--307.

Davis, M.L. and D.A. Cornwell. 1991. Introduction to Environmental Engineering. Second edition. Mc-Graw-Hill, Inc., New York. 822 pp.

Draper, N.R. and H. Smith. 1981. Applied Regression Analysis. Second Edition. John Wiley \& Sons, New York. 709 pp.

Eldani, A. and J.H. Primavera. 1981. Effect of different stocking combination of growth, production and survival rate of milkfish (Chanos chanos Forskal) and prawn (Penaeus monodon Fabricius) in polyculture in brackishwater ponds. Aquaculture. 23: 59-72.

Fattah, M.H. dan St. R. Busaeri. 2003. Perubahan perilaku manajemen petani penerima bantuan saluran tambak "studi kasus: penanggulangan penyakit pada udang windu secara terpadu berbasis hamparan". Jurnal Ilmiah Mutiara. II(3): 12-22.

Furukawa, I., H. Hidare, and K. Hiramo. 1973. Production of prawn seed by marine yeast. Research Report Faculty of Agriculture Miyosaki University. 20(1): 93--110.

Hanafi, A. 1990. Socio-economic and managerial profiles of brackishwater aquaculture in South Sulawesi. J. Per. Budidaya Pantai. 6(2): 97--114.

Hickling, C.F. 1971. Fish Culture. Second edition. Faber and Faber, London. 295 pp.

Ilyas, S., F. Cholik, A. Poernomo, W. Ismail, R. Arifudin, T. Daulay, A. Ismail, S. Koesoemadinata, I N.S. Rabegnatar, H. Soepriyadi, H.H. Suharto, Z.I. Azwar, dan S.E. Wardoyo. 1987. Petunjuk Teknis bagi Pengoperasian Unit Usaha Pembesaran Udang Windu. Pusat Penelitian dan Pengembangan Perikanan, Jakarta. 100 pp.

Islam, M.S., A. Milstein, M.A. Wahab, A.H.M. Kamal, and S. Dewan. 2005. Production and economic return of shrimp aquaculture in coastal ponds of different management regimes. Aquaculture International. 13: 489--500.

Karthik, M., J. Suri, N. Saharan, and R.S. Biradar. 2005. Brackish water aquaculture site selection in Palghar Taluk, Thane district 
of Maharashtra, India, using the techniques of remote sensing and geographical information system. Aquacultural Engineering. 32: 285--302.

Kuhl, A. 1974. Phosphorus. In: Stewart, W.D.P. (Ed.). Algal Physiology and Biochemistry. Botanical Monographs. Volume 10. Blackwell Scientific Publication, Oxford, London, Edinburgh, Melbourne. p. 636-654.

Ling, B. -H., P.S. Leung, and Y.C. Shang. 2001. Comparing Asian shrimp farming: the domestic resource cost (DRC) approach. In: Leung, P.S. and Sharma, K.R. (Eds.), Economics and Management of Shrimp and Carp Farming in Asia. Network of Agriculture Centers in Asian-Pacific, Bangkok. p. 13--31.

Lin, H.S. 1969. Some aspects of milkfish ecology. Chinese-American Joint Commission for Rural Reconstruction. Fisheries Series. 17: 68--90.

McNeely, R.N., V.P. Nelmanis, and L. Dwyer. 1979. Water Quality Source Book, A Guide to Water Quality Parameter. Inland Waters Directorate, Water Quality Branch, Ottawa. $89 \mathrm{pp}$.

Meagaung, W.M., M.N. Nessa, A. Hanafi, dan M.N. Jalaluddin. 2000. Faktor-faktor dominan yang berpengaruh terhadap akumulasi bahan organik pada tambak udang intensif. Lingkungan \& Pembangunan. 20(1): 43--51.

Melville, M.D. 1993. Soil Laboratory Manual. School of Geography, The University of New South Wales, Sydney. 74 pp.

Menon, R.G. 1973. Soil and Water Analysis: A Laboratory Manual for the Analysis of Soil and Water. Proyek Survey O.K.T. Sumatera Selatan, Palembang. 191 pp.

Milstein, A., M.S. Islam, M.A. Wahab, A.H.M. Kamal, and S. Dewan. 2005. Characterization of water quality in shrimp ponds of different size and with different management regimes using multivariate statistical analysis. Aquaculture International. 13: 501--518.

Moore, J.W. 1991. Inorganic Contaminants of Surface Water. Springer-Verlag, New York. $334 \mathrm{pp}$.

Muluk, C. and C. Baily. 1996. Social and environmental impacts of coastal aquaculture in Indonesia. In: Baily, C., Jentoft, S., and Sinclair, P. (Eds.), Aquaculture Development. Westview Press, Boulder, Colorado. p. 193$-210$.

Mustafa, A. 2006. Improving Acid Sulfate Soils for Brackish Water Aquaculture Ponds in
South Sulawesi, Indonesia. Doctor of Philosophy Thesis. The University of New South Wales, Sydney. 418 pp.

Mustafa, A. dan E. Ratnawati. 2005. Faktor pengelolaan yang berpengaruh terhadap produksi rumput laut (Gracilaria verrucosa) di tambak tanah sulfat masam (studi kasus di Kabupaten Luwu, Provinsi Sulawesi Selatan). J. Pen. Per. Indonesia. 11 (7): 67-77.

Padlan, P.G., A. Poernomo, and K.H. Alikunhi. 1975. Year-round, multiple cropping to increase production of milkfish, Chanos chanos, from shallow brackish water ponds. Bulletin of Shrimp Culture Research Centre. I(2): 79--98.

Poernomo, A. 1988. Pembuatan Tambak Udang di Indonesia. Seri Pengembangan No. 7. Balai Penelitian Perikanan Budidaya Pantai, Maros. 30 pp.

Ranoemihardjo, B.S., A. Kahar, and J.V. Lopez. 1979. Results of polyculture of milkfish and shrimp at the Karanganyar provincial demonstration ponds. Bulletin of Brackishwater Aquaculture Development Center. 5(1\&2): 334--350.

Ratnawati, E., A.M. Tangko, dan A. Mustafa. 2002. Aspek sosial ekonomi petambak tradisional di Kabupaten Pinrang, Sulawesi Selatan. Dalam: Sibuea, L.H., Baco, M. D., Saenong, S., Sastramihardja, H., Ella, A. dan Pasaribu, A.M. (Eds.), Prosiding Ekspose Nasional Penelitian dan Pengembangan Pertanian. Buku II. Pusat Penelitian dan Pengembangan Tanah dan Agroklimat, Bogor. p. 649658.

Riley, J.P. and R. Chester. 1971. Introduction to Marine Chemistry. Academic Press, London. 465 pp.

Shang, Y.C. 1976. Economic comparison of milkfish farming in Taiwan and the Philippines, 1972-1975. Aquaculture. 9: 229--236.

Shang, Y.C. 1986. Pond production systems: stocking practices in pond fish culture. In: Lannan, J.E., Smitherman, R.O. and Tchobanoglous, G. (Eds.), Principles and Practices of Pond Aquaculture. Oregon State University Press, Corvallis, Oregon. p. 85--96.

Sugihen, B.T. 1996. Sosiologi Pedesaan (Suatu Pengantar). PT RajaGrafindo Persada, Jakarta. 183 pp.

Tsai, C.-K. 1989. Water quality management. In: D.M. Akiyama (ed.), Proceedings of the Southeast Asia Shrimp Farm Management 
Workshop. American Soybean Association, Singapore. p. 56--63.

Villaluz, A.C. and A.S. Unggui. 1983. Effect of temperature on behavior, growth, development and survival of young milkfish, Chanos chanos (Forskal). Aquaculture. 35: 321--330.
Wickins, J.F. 1984. The effect of reduced pH on carapace calcium, strontium and magnesium levels in rapidly growing prawns (Penaeus monodon Fabricius). Aquaculture. 41: 49--60.

Wirartha, I.M. 2006. Metodologi Penelitian Sosial Ekonomi. Penerbit Andi, Yogyakarta. 383 pp. 